\title{
PLANKTONIC CILIATES CHOREOTRICHIDA AND STROMBIDIIDA FROM THE INNER ZONE OF BAHÍA BLANCA ESTUARY, ARGENTINA
}

\author{
Rosa E. Pettigrosso ${ }^{1}$
}

\begin{abstract}
Seven species of aloricate planktonic ciliates were identified using protargol staining. Choreotrichida: Strombidinopsidae, Strombidinopsis elongata Song \& Bradbury, 1998; Strobiliidae, Strobilidium epacrum Lynn \& Montagnes, 1988 and Strombidiida: Strombidiidae, Strombidium capitatum (Leegaard, 1915) Kahl, 1932; S. emergens (Leegaard, 1915) Kahl, 1932; S. acutum Leegaard, 1915; S. dalum Lynn, Montagnes \& Small, 1988 and Cyrtostrombidium longisomum Lynn \& Gilron, 1993; they were collected from the inner zone of the Bahía Blanca estuary in the southern region of the Buenos Aires province, Argentina. These species represent new records to South America (Argentina).
\end{abstract}

KEYWORDS. Planktonic ciliates, estuary, distribution.

\section{INTRODUCTION}

In last decades the importance of ecological function of micro-organisms in pelagic food webs has been recognized and many studies have been carried out, principally in Europe and North America. Planktonic ciliates constitute a diverse group in a trophic and taxonomic point of view. They are often the dominants of the heterotrophic planktonic protists, representing a link between phytoplankton and higher trophic levels. Investigations show that aloricate ciliates occur in high numbers and consume significant quantities of autotrophic and heterotrophic microbial production (AzAm et al., 1983; Fenchel, 1987; Montagnes \& LynN, 1991). They are eaten in turn by other protozoans, many metazoans and fish larvae (Jonsson, 1986; PierCe \& TURNER, 1992; Lonsdale et al., 1996; Petz, 1999). The taxonomic composition and ecological characteristics of the aloricated planktonic ciliates from South Atlantic Ocean and coastal zone of Argentina are poorly known.

The aim is to report the assessment of the composition of the aloricate ciliates community in the inner zone from Bahía Blanca estuary, Argentina.

1. Universidad Nacional del Sur, Departamento de Biología, Bioquímica y Farmacia, San Juan 670, (8000) Bahía Blanca, Argentina. (fipetti@criba.edu.ar) 


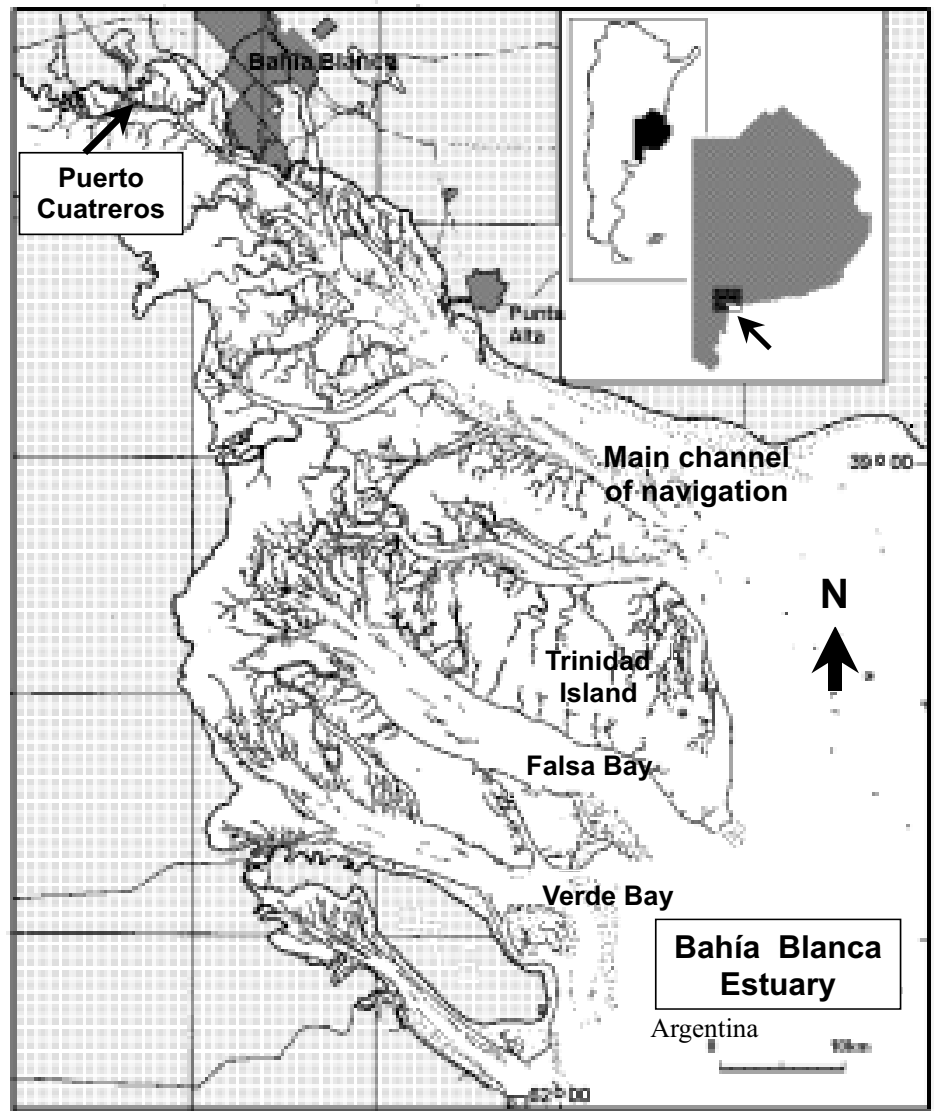

Fig. 1. The Bahía Blanca estuary, Argentina, showing the location of Puerto Cuatreros.

\section{MATERIAL AND METHODS}

Bahía Blanca estuary is located on the Atlantic coast at $38^{\circ} 42^{\prime}-39^{\circ} 25^{\prime} \mathrm{S}, 61^{\circ} 50^{\prime}-62^{\circ} 22^{\prime} \mathrm{W}$. It has a total length of $68 \mathrm{~km}$, being $200 \mathrm{~m}$ and 3 to $4 \mathrm{~km}$ wide near its head and mouth, respectively. It is a semienclosed body of water characterized as shallow, well mixed and with high turbidity due to a great amount of organic and inorganic suspended material. Strong winds and tidal waves dominate the general circulation (Piccolo \& Perillo, 1990).

Sampling was done in Puerto Cuatreros located in the inner part of the estuary, near its head (fig. 1), from February $1^{\text {st }}, 1994$ to February $22^{\text {nd }}, 1995$. This part has variable temperature and salinity. The Sauce Chico River, the Napostá Grande stream and other minor creeks, that discharge in the estuary only during rainfall periods, carry most of the freshwater inflow and in dry summers it becomes hypersaline (FREIJE et al., 1981). Water samples were taken out at weekly intervals during daylight hours and high tide from the subsurface $(0.50-1 \mathrm{~m})$, using a $3 \mathrm{~L}$ Van Dorn bottle. Data of temperature and salinity were also registered. Protargol staining, according to TufFrau (1967); LeE et al. (1985) and FoISSNER (1991) was used to estimate the taxonomic composition. Protargol stained species were deposited in the collection of the Laboratorio de Ecología General, Departamento de Biología, Bioquímica y Farmacia, Universidad Nacional del Sur, Bahía Blanca, Argentina. 


\section{RESULTS AND DISCUSSION}

The seven species reported in Puerto Cuatreros belong to the orders Choreotrichida and Strombidiida. They are commonly found in other coastal areas of the world (LyNN et al., 1988; Montagnes et al., 1988; Lynn \& Gilron, 1993; Leakey et al., 1994; Petz et al., 1995; Song \& BRADBURY, 1998). Some differences in cell size and in numbers of several structures from Puerto Cuatreros populations were observed. Montagnes et al. (1988) have demonstrated that spirotrichs show marked size variation in response to environmental influences and regulate numbers of structures in proportion to cell size.

Free-living phagotrophic protozoans are usually believed to have a cosmopolitan distribution and it seems that in environments with similar characteristics the same species could be present (FENCHEL, 1987). The taxonomy and ecology of marine aloricate planktonic ciliates have only recently been described with some frequency using modern cytological techniques thus, little is known about their global distribution and it is difficult to know which species have truly restricted geographic ranges (PIERCE \& Turner, 1992; PetZ, 1999).

Temperature and salinity values registered in Puerto Cuatreros during the study were similar to those encountered in other parts of the world where the same species of aloricate ciliates were also found. These observations would confirm the hypothesis that protozoan species in coastal areas are widely distributed (FeNCHEL, 1987). However, Strombidium emergens was recorded at geographically different sites (Weddell Sea; Gulf of Maine, USA and Puerto Cuatreros) and in water temperature quite different. Thus, it is possible that species from different geographical regions have different temperature tolerances (LYNN et al., 1991).

\section{Spirotrichea, Choreotrichida, Strombidinopsidae Strombidinopsis elongata Song \& Bradbury, 1998}

(Figs. 2, 3)

Strombidinopsis elongata Song \& BRADBURY, 1998:785, fig. 6.

Description. Large cell, 97.5-128.7 length, 74-82 width $(\mathrm{n}=13)$. Cylindrical body shape with a pointed posterior end; 14-18 longitudinal somatic kineties evenly distributed around the cell. Two spherical to ovoid macronucleus 12-17.6 length to 12-15.6 width positioned in centre of the cell (fig. 2). Diameter of adoral zone 39-51. External oral polykinetid zone composed of 17-20 polikinetids. Inner oral polykinetid zone with 4-6 polikinetids, which three of them are independent and located in an oral depression (fig. 3). Micronucleus not observed.

Occurrence. The species was present in Puerto Cuatreros mainly in winter months when the diatom bloom occurs; salinity $29.6-35.7 \%$, temperature $8.8-11^{\circ} \mathrm{C}$.

Distribution. Yellow Sea, northeastern of China (Song \& BRADBURY, 1998); Puerto Cuatreros, Bahía Blanca estuary, Argentina.

Environmental parameters. Oligo to mesosaprobic coastal waters, salinity $30-32 \%$, temperature $5-24^{\circ} \mathrm{C}$.

Taxonomical remarks. The population of Strombidinopsis elongata from Puerto Cuatreros differs from the population described in north of China (SONG \& BRADBURY, 1998) by having larger cell and macronucleous, but the similarities in body shape, number of external oral polikynetids and somatic kineties justify the assignment of these specimens to $S$. elongata. 

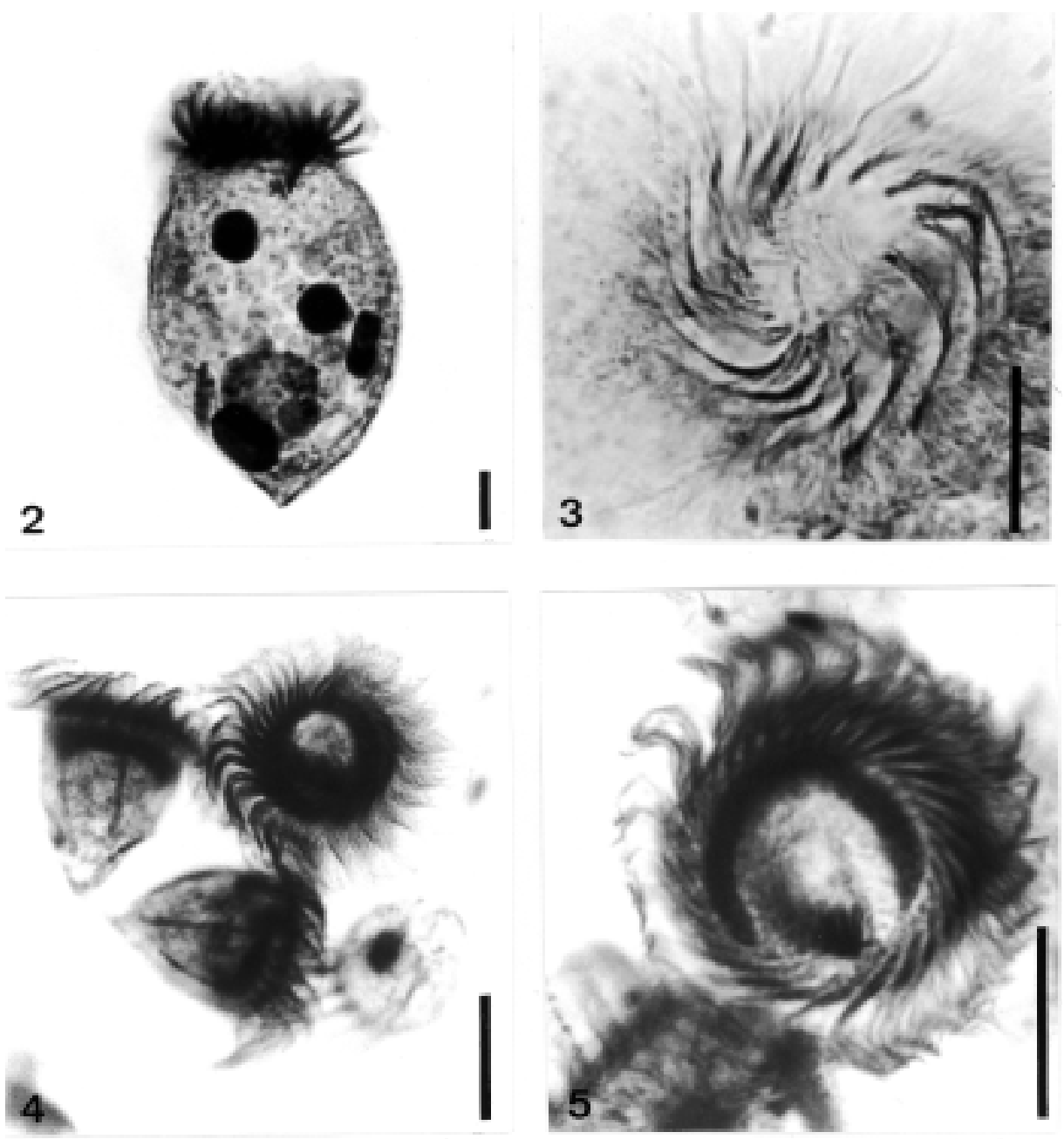

Figs. 2-5. Protargol impregnated ciliate species from Puerto Cuatreros: 2, Strombidinopsis elongata Song \& Bradbury, 1998, general view; 3, anterior oral polykinetid zone; 4, Strobilidium epacrum Lynn $\&$ Montagnes, 1988, general view; 5, anterior oral polykinetid zone. Scale bars, $20 \mu \mathrm{m}$ : figs. 2,3; 4,5, respectively in the same scale.

\section{Strobilidiina, Strobiliidae \\ Strobilidium epacrum Lynn \& Montagnes, 1988}

(Figs. 4, 5)

Strobilidium epacrum Lynn \& Montagnes, 1988:643, fig. 2.

Description. Conical cell shape with pointed posterior end, 35-55 length, 31-47 width (fig. 4) (n=3). Five somatic kineties of various lengths covered with cytoplasmic 
flaps. On dorsal region, kinety 2 spiralled, extending from posterior to anterior, kinety 3 short, in the middle of the body and kinety 4 longitudinally, longer than kinety 3 . On ventral region found kinety 1 , halfway down cell and kinety 5 extended longitudinally. Macronucleous C-shaped with ventral opening. External oral polykinetid zone composed of 30-31 polykinetids. Inner oral polykinetid zone composed of 6-8 polykinetids, six of them continuous with the external polykinetids and two independent. The internal polykinetids are situated in the oral depression (fig. 5).

Ocurrence. In Puerto Cuatreros this species was frequent in spring; salinity $30-38 \%$, temperature $12-18^{\circ} \mathrm{C}$.

Distribution. Neritic waters near the Isles of Shoals, Gulf of Maine, USA (Lynn \& Montagnes, 1988); Puerto Cuatreros, Bahía Blanca estuary, Argentina.

Taxonomical remarks. Except for the cell size, the specimens from Puerto Cuatreros (35-55 length) match well with the population described by Lynn \& Montagnes (1988) (60-95 length).

\section{Strombidiida, Strombidiidae \\ Strombidium capitatum (Leegaard, 1915) Kahl, 1932}

(Figs. 6, 7)

Laboea capitata LEEGAARD, 1915:16, fig. 6.

Strombidium capitatum; KAhL, 1932:503, fig. 20; MAEda \& CARey, 1985:51, fig. 88; Montagnes et al., 1988:192, fig. 2 .

Description. Cylindrical body shape, 23-51 length, 39-55 width (n=11) (fig. 6). A conspicuous peristomial collar and a large, wide and deep oral groove at the anterior part of the cell. Trichites in radial arrangement inserting at the posterior end. Subequatorial kinety surrounds the cell. Anterior polykinetid zone and ventral polykinetid zone separated. Anterior polykinetid zone composed of 16-18 polykinetids. Ventral polykinetid zone composed of 18-20 polykinetids. A paroral membranell in the inner part of the oral groove. One macronucleous elongated (fig. 7).

Occurrence. In Puerto Cuatreros S. capitatum was frequent in October and December; salinity $29-30 \%$, temperature $12-21^{\circ} \mathrm{C}$.

Distribution. Great Harbor, Woods Hole, Massachusetts, USA (MonTAGnEs et al., 1988); Puerto Cuatreros, Bahía Blanca estuary, Argentina.

Environmental parameters. Salinity 31-32\%o, temperature 5-24 ${ }^{\circ}$; eurythermal.

Food. Mixotrophic, nanoflagellates.

Taxonomical remarks. Cellular features of $S$. capitatum from Puerto Cuatreros are similar to those described by MonTAGNes et al. (1988).

\section{Strombidium acutum Leegaard, 1915}

(Figs. 8, 9)

Strombidium acutum LeEgaARd, 1915:31, fig. 21; MAEda \& CARey, 1985:56, fig. 97; Montagnes et al., 1988:192, fig. 6; LYNN et al., 1988:262, fig. E.

Description. Conical shape 27-33 in length, 27-35 in width (n=10) (fig. 8). Anterior polykinetid zone distinctly separated from ventral polykinetid zone. Anterior polykinetid zone composed of 12-16 polykinetids. Ventral polykinetid zone composed of 10-12 

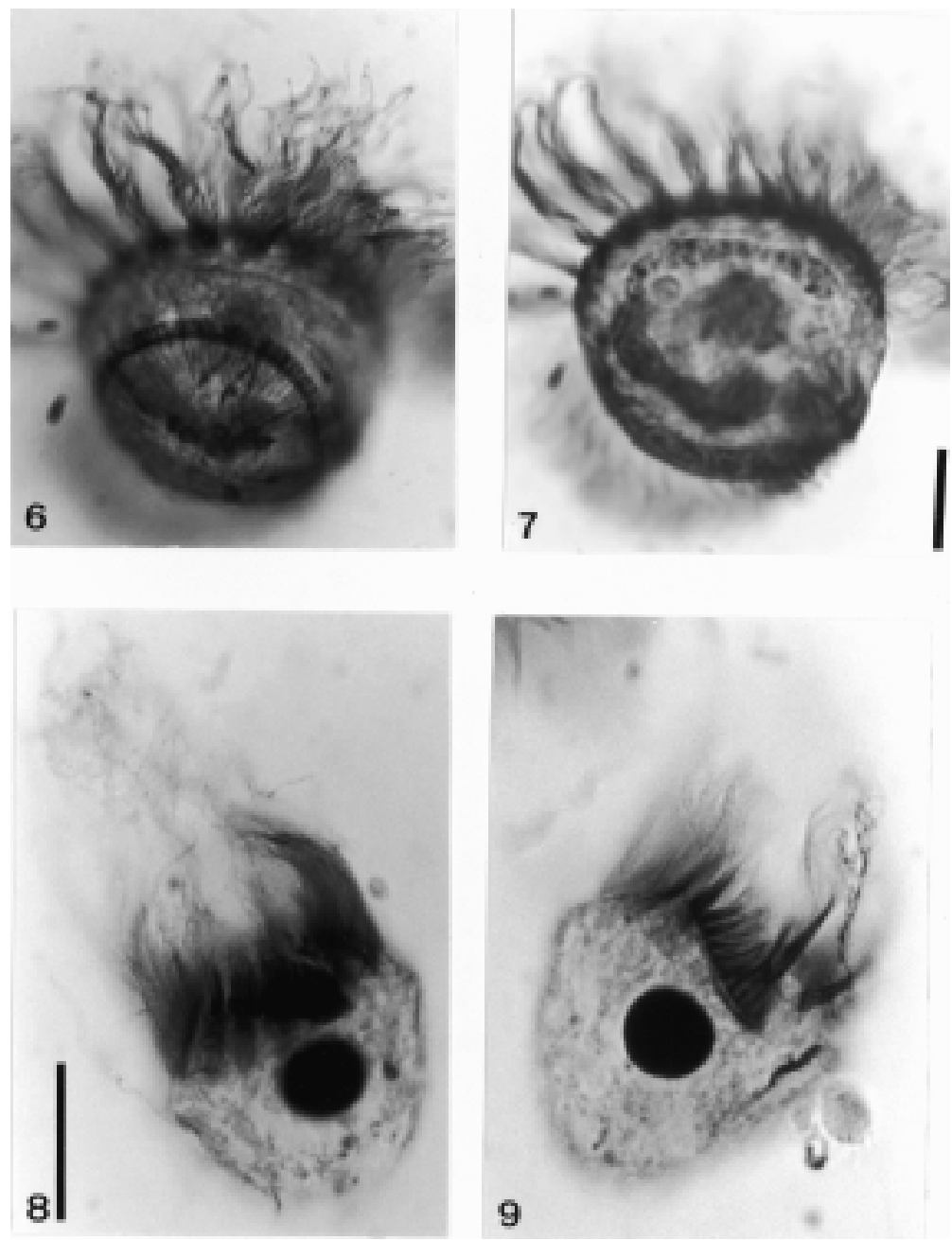

Figs. 6-9. Protargol impregnated ciliate species from Puerto Cuatreros: 6, Strombidium capitatum (Leegaard, 1915) Kahl, 1932, general view; 7, nuclear detail; 8, Strombidium acutum Leegaard, 1915, general view showing filamentous material belonging to the trichites; 9, ventral view. Scale bars, $20 \mu \mathrm{m}$ : figs.6,7; 8,9, respectively in the same scale.

polykinetids located in a shallow ventral groove. Girdle kinety supraequatorial surrounding the cell. One spherical macronucleous 8-19 in diameter centrally positioned. Large trichites inserted near girdle. Filamentous material belonging to the extruding trichites interlaced with anterior cilia characterizes this species (fig. 9).

Occurrence. In Puerto Cuatreros $S$. acutum was observed in spring and summer; salinity $30-35 \%$, temperature $12-19^{\circ} \mathrm{C}$.

Distribution. Neritic waters near the Isles of Shoals, Gulf of Maine, USA (LYNN et 

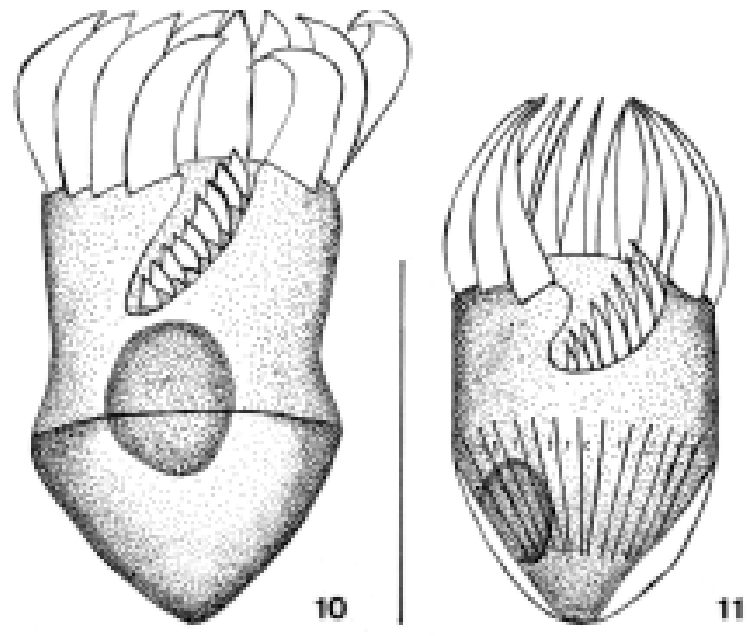

Figs. 10, 11. Protargol impregnated ciliate species from Puerto Cuatreros: 10, Strombidium emergens (Leegaard, 1915) Kahl, 1932, general view; 11, Strombidium dalum Lynn, Montagnes \& Small, 1988, general view. Scale bars, $20 \mu \mathrm{m}$.

al., 1988); Perch Pond, Falmouth, Massachusetts, USA (MonTAGnes et al., 1988); Puerto Cuatreros, Bahía Blanca estuary, Argentina.

Environmental parameters. Salinity $24-32 \%$, temperature $7-20^{\circ} \mathrm{C}$.

Food. Mixotrophic, autotrophic flagellates.

Taxonomical remarks. The specimens was determined according to the description of LynN et al. (1988). The specimens from Puerto Cuatreros have smaller cell than those described by these authors, but they have registered a great variability of this character among populations of this species.

\section{Strombidium emergens (Leegaard, 1915) Kahl, 1932}

(Fig. 10)

Laboea emergens LEEGAARD, 1915:21, fig. 11.

Strombidium emergens; Kahl, 1932:501, fig. 13; Montagnes et al., 1990:320, fig. Q; Petz et al., 1995:115-117, figs. 35 a-c.

Strombidium sulcatum; LYNN et al., 1988:268, fig. E (non Claparéde \& Lachmann, 1858).

Description. Anterior portion of the body cylindrical, posterior conical, 27-39 length, 19.5-29 wide $(\mathrm{n}=7)$. Subequatorial girdle kinety all around the cell. Anterior polykinetid zone and ventral polykinetid zone separated; the anterior composed of 12-14 polykinetids, ventral with 9-11 polykinetids located in a ventral groove. Macronucleuous spherical to ovoid, 6-12 large, 6-16 wide positioned in centre of the cell (fig. 10).

Occurrence. In Puerto Cuatreros was observed in winter, salinity 30-33\%o, temperature $9-12^{\circ} \mathrm{C}$.

Food. Mixotrophic, autotrophic flagellates.

Distribution. Neritic waters near the Isles of Shoals, Gulf of Maine, USA; ecological 
parameters: salinity $26-32 \%$, temperature $10-20^{\circ} \mathrm{C}$ (LynN et al., 1988). Weddell Sea (69 $46^{\prime}$ $70^{\circ} 21^{\prime} \mathrm{S}, 08^{\circ} 53^{\prime}-11^{\circ} 00^{\prime} \mathrm{W}$ ).

Environmental parameters. Salinity ca. 50\%o, temperature -2,6 ${ }^{\circ} \mathrm{C}$ (PETZ et al., 1995); Puerto Cuatreros, Bahía Blanca estuary, Argentina.

Taxonomical remarks. Puerto Cuatreros population of Strombidium emergens is similar to the population described by LYNN et al. (1988) as Strombidium sulcatum. This population was later determined as Strombidium emergens by MoNTAGNES et al. (1990).

\section{Strombidium dalum Lynn, Montagnes \& Small, 1988}

(Fig. 11)

Strombidium dalum LyNN et al., 1988:266, fig. 3 A.

Description. Conical shape, 12-37 length, 12 width $(\mathrm{n}=8)$. Anterior polykinetid zone distinctly separated from ventral polykinetid zone. Anterior polykinetid zone composed of 10-12 polykinetids. Ventral polykinetid zone with 8 polykinetids located in a ventral groove. Girdle kinety equatorial. Long trichites inserting anteriorly to girdle kinety and extending near to posterior end, in radial arrangement. One macronucleous 4-8 in diameter, conical to spherical, located at posterior end (fig. 11).

Occurrence. In Puerto Cuatreros was observed in spring; salinity 30-31\%o, temperature $9-13^{\circ} \mathrm{C}$

Distribution. Neritic waters near the Isles of Shoals, Gulf of Maine, USA (Lynn et al., 1988). Coastal waters near Kingston Harbour, Jamaica (LynN \& GiLRon, 1993); Puerto Cuatreros, Bahía Blanca estuary, Argentina.

Environmental parameters. Salinity $26-36 \%$, temperature $5-20^{\circ} \mathrm{C}$.

Taxonomical remarks. The population of Puerto Cuatreros is similar in size to those of the Gulf of Maine and Jamaican coast described by LYNN et al. (1988) and LyNN \& GILRON (1993). It has a similar number of anterior and ventral oral polykinetids and it has a similar macronucleous spherical to conical shape. The specimens of $S$. dalum recorded in Puerto Cuatreros do not show either the ventral kinety, present only in the Jamaican one (LYNN \& GILRON, 1993) nor the "torch-like" shape of the cilia of the anterior polikinetid zone present only in the Gulf of Maine population (LyNn et al., 1988). Ventral kinety was a characteristic apparently overlooked in the Gulf of Maine population and the torch-like shape of the cilia was considered an artefact of fixing and staining in the Jamaican population.

\section{Cyrtostrombidium longisomum Lynn \& Gilron, 1993}

(Fig. 12)

Cyrtostrombidium longisomum LynN \& GiLRon, 1993:61, figs. 6 A-C.

Description. Conical shape, 47-74 length, 19.5-31 width $(\mathrm{n}=4)$. Anterior polykinetidal zone composed of 10 polykinetids, surrounding the anterior end that bears a spherical protuberance. No ventral polykinetidal zone. Ventral kinety composed of dikinetids, with one kinetosome ciliated. Basquet of fibres around the cytopharynx. One large elongate macronucleous 17.5-25 length, 4-6 width. Micronucleous not impregnated. Cytoplasm filled with inclusions, probably pigments of green algae. Cell covered with polysaccharid 


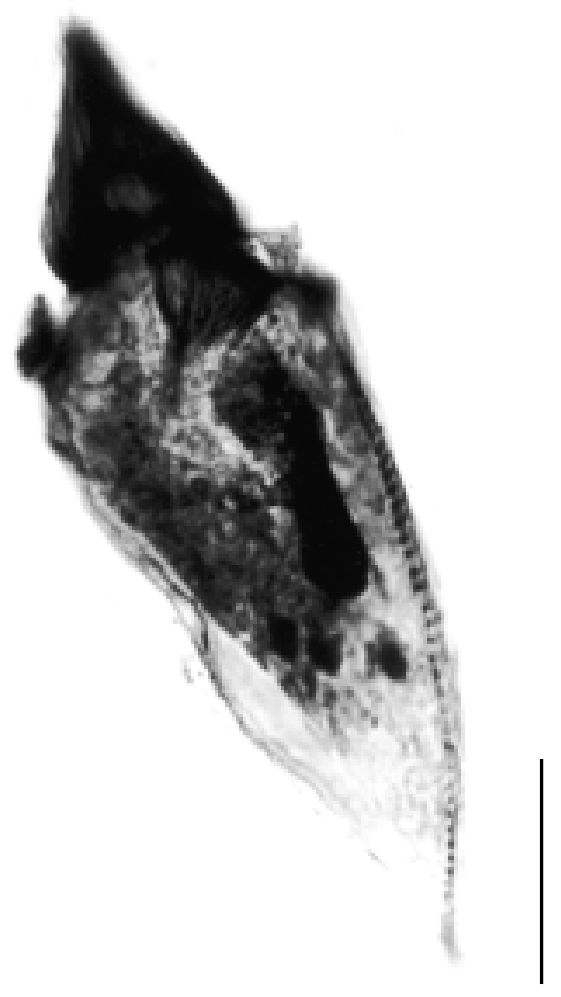

Fig. 12. Protargol impregnated ciliate species from Puerto Cuatreros: Cyrtostrombidium longisomum Lynn \& Gilron, 1993, right lateral and internal view. Scale bar, $20 \mu \mathrm{m}$. plates. Distended cell surface present (fig. 12).

Occurrence. In Puerto Cuatreros was recorded in spring; salinity 29-35.5\%o, temperature $11-22^{\circ} \mathrm{C}$.

Distribution. Coastal waters near Kingston Harbour, Jamaica (LynN \& Gilron, 1993), Plymouth Sound, Southampton waters (Leakey et al., 1994); Puerto Cuatreros, Bahía Blanca estuary, Argentina.

Environmental parameters. Salinity $34.8 \%$, temperature $14.4^{\circ} \mathrm{C}$. Taxonomical remarks. Cyrtostrombidium longisomum from Puerto Cuatreros is similar to the Jamaican population (LYNN \& GiLron, 1993) in the body shape, by the presence of a protuberance, a ventral kinety and in the shape and size of the macronucleous. The cell of the Puerto Cuatreros population is larger and shows polysaccharid plates not reported for the Jamaican population. This last feature could be considered a characteristic of the environment.

Acknowledgments. To Dr. Denis Lynn (Zoology Department, University of Guelph) for help with the determination of the species and to Dr. Virginia Vianchinotti (Universidad Nacional del Sur) for help to improve the manuscript.

\section{REFERENCES}

Azam, F.; Fenchel, T. et al. 1983. The ecological role of water-column microbes in the sea. Mar. Ecol. Progr. Ser., Oldendorf, 10:257-263.

Fenchel, T. 1987. Ecology of Protozoa. Madison, Science Tech. 197p.

Folssner, W. 1991. Basic light and scanning electron microscopic methods for taxonomic studies of ciliated protozoa. Europ. J. Protistol., Stuttgart, 27:313-330.

FREIJE, R. H. et al. 1981. Relación de la salinidad y temperatura del agua con las condiciones hidrometeorológicas en la porción interna del estuario de Bahía Blanca. Bahía Blanca, Instituto Argentino de Oceanografía. 20p. (Contribuição Científica, 57)

Jonsson, P. R. 1986. Particle size selection, feeding rates and growth dynamics of marine planktonic oligotrichous ciliates (Ciliophora: Oligotrichina). Mar. Ecol. Progr. Ser., Oldendorf, 33:265-277.

KAHL, A. 1932. Urtiere oder Protozoa I: Wimpertiere oder Ciliata (Infusoria) 3. Spirotricha. In: DAHL, F. ed. Die tierwelt Deutschlands und der angrenzenden meeresteile. Jena, Gustav Fisher. v.25, p.487-518. 
Leakey, R. J. G.; Burkill, P. H. \& Sleigh, M. A. 1994. A comparison of fixatives for the estimation of abundance and biovolumen of marine planktonic ciliate populations. J. Plankton Res., Oxford, 16(4):375-389.

Lee, J. J.; Small, E. B. et al. 1985. Some techniques for collecting, cultivating and observing protozoa. In: Lee, J. J.; Hutner, S. H. \& Bovee, E. C. eds. An illustrated guide to the Protozoa. Lawrence, Society of Protozoologists Special Publ. Allen. 629p.

LeEgaARd, C. 1915. Untersuchungen über einige planktonciliaten des meeres. Nyt. Mag. f. Naturv., Oslo, 53:1-37.

Lonsdale, D. J.; Cosper, E. M. et al. 1996. Food web interactions in the plankton of Long Island bays, with preliminary observations on brown tide effects. Mar. Ecol. Progr. Ser., Oldendorf, 134:247-263.

Lynn, D. H. \& Gilron, L. G. 1993. Strombidiid ciliates from coastal waters near Kingston Harbour, Jamaica (Ciliophora, Oligotrichia, Strombiidae). J. Mar. Biol. Assoc. UK, London, 73:47-65.

Lynn, D. H. \& Montagnes, D. J. S. 1988. Taxonomic descriptions of some conspicuous species of strobilidiine ciliates (Ciliophora: Choreotrichida) from the Isles of Shoals, Gulf of Maine. J. Mar. Biol. Assoc. UK, London, 68:639-658.

Lynn, D. H.; Montagnes, D. J. S. et al. 1991. A reassessment of the genus Strombidinopsis (Ciliophora, Choreotrichida) with descriptions of four new planktonic species and remarks on its taxonomy and phylogeny. J. Mar. Biol. Assoc. UK, London, 71:597-602.

Lynn, D. H.; Montagnes, D. J. S. \& Small, E. B. 1988. Taxonomic descriptions of some conspicuous species in the family Strombidiidae (Ciliophora: Oligotrichida) from the Isles of Shoals, Gulf of Maine. J. Mar. Biol. Assoc. UK, London, 68:259-276.

Maeda, M. \& CARey, P. 1985. An illustrated guide to the species of the family Strombiidae (Oligotrichida, Ciliophora), free swimming protozoa common in the aquatic environment. Bull. Ocean. Res. Inst. Univ. Tokyo, Tokyo, 19:1-68.

Montagnes, J. S. D. \& Lynn, D. H. 1991. Taxonomy of choreotrichs, the major marine planktonic ciliates, with emphasis on the aloricate forms. Mar. Microb. Food Webs, New York, 5(1):59-74.

Montagnes, J. S. D.; Lynn, D. H. et al. 1988. Taxonomic descriptions of one new species and redescription of four species in the family Strombiidae (Ciliophora, Oligotrichida). J. Protozool., Lawrence, 35(2):189-197.

Montagnes, J. S. D.; Taylor, F. J. R. \& Lynn, D. H. 1990. Strombidium inclinatum n. sp. and a reassessment of Strombidium sulcatum Claparède and Lachmann (Ciliophora). J. Protozool., Lawrence, 37(4):318-323.

Petz, W. 1999. Ciliophora. In: Boltoskoy, D. South Atlantic zooplankton. Leiden, Backhuys Publ. p.265-319.

Petz, W.; Song, W. \& Wilbert, N. 1995. Taxonomy and ecology of the ciliate fauna (Protozoa, Ciliophora) in the endopelagial and pelagial of the Weddell Sea (Antarctica). Stapfia, Linz, 40:1223.

Piccolo, M.C. \& Perillo, M. E. 1990. Physical characteristics of the Bahía Blanca estuary Argentina. Estuar. coast. shelf Sci., London, 31:303-317.

Pierce, W. R. \& Turner, J. T. 1992. Ecology of planktonic ciliates in marine food webs. Rev. Aquat. Sci., Florida, 6(2):139-181.

Song, W. \& Bradbury, C. P. 1998. Studies on some new and rare reported marine Planktonic ciliates (Ciliophora: Oligotrichida) from coastal waters in north China. J. Mar. Biol. Assoc. UK, London, 78:767-794.

Tuffrau, M. 1967. Perfectionnements et practique de la technique d'imprégnation au protargol des infusoires ciliés. Protistologica, Paris, 3:91-98.

Recebido em 30.04.2002; aceito em 12.11.2002. 